\title{
Three objectives of historical ecology \\ The case of litter collecting in Central European forests
}

\section{Review Article}

Author(s):

Buergi, Matthias; Gimmi, Urs

Publication date:

2007-12

Permanent link:

https://doi.org/10.3929/ethz-b-000058945

Rights / license:

In Copyright - Non-Commercial Use Permitted

Originally published in:

Landscape Ecology 22(Supplement 1), https://doi.org/10.1007/s10980-007-9128-0 


\title{
Three objectives of historical ecology: the case of litter collecting in Central European forests
}

\author{
Matthias Bürgi · Urs Gimmi
}

Received: 3 August 2006/Accepted: 13 July 2007/Published online: 31 July 2007

(C) Springer Science+Business Media B.V. 2007

\begin{abstract}
Most ecosystems and landscapes worldwide are dominated or influenced by human impacts. Consequently, studies of pattern and processes of and within anthropogenic ecosystems and cultural landscapes have to consider human impacts and their historical development adequately. Three major objectives of historical ecology, i.e., the study of human impacts on ecosystems and landscapes over time, can be distinguished: (a) preserving cultural heritage in ecosystems and landscapes, (b) understanding historical trajectories of pattern and processes in ecosystems and landscapes, and (c) informing ecosystem and landscape management. In this paper, the application of these three major objectives of historical ecology is illustrated with a case study on litter collecting - a largely forgotten traditional forest use in Central Europe. Historical analyses do not allow-and should not be misusedto directly deduct management goals, as goals need to be set based on present needs and demands. Still, information on reference condition is relevant in the process of defining goals. Once specific goals are set, historical ecology may advise on how to best achieve and maintain desirable pattern and processes in ecosystems or landscape.
\end{abstract}

M. Bürgi $(\bowtie) \cdot$ U. Gimmi

Research Group Land Use History, Swiss Federal

Research Institute WSL, Zürcherstrasse 111,

8903 Birmensdorf, Switzerland

e-mail: matthias.buergi@wsl.ch
Keywords Ecological processes .

Anthropogenic disturbances · Cultural heritage ·

Land-use history · Cultural landscape .

Trajectories

\section{Introduction}

Humans are an exceptionally powerful biotic factor (Williams 1993) — a fact that has been long recognized. Several classics, such as "Man and Nature; or, Physical Geography as Modified by Human Action" by the American Geographer George Perkins Marsh, published in 1864 (Marsh 2003), serve as landmarks in this early debate. However, it is not until the last decades that we have started to grasp the extent to which humans dominate the earth and to assess the related risks (e.g., Goudie 1981; Birks et al. 1988; Simmons 1989; Turner 1990). For many millennia, human impacts have shaped the appearance and function of regions, landscapes, and ecosystems. Landscapes that have a historical dimension therefore are rightfully called cultural or anthropogenic landscapes (e.g., Hammett 1992). Similarly, ecosystems influenced by humans, might be called cultural or anthropogenic ecosystems. Cultural landscapes as well as anthropogenic ecosystems cannot be understood without taking human impacts and their change over time into account (Berger 1987; Nassauer 1997; Vitousek et al. 1997). A thorough understanding of human impacts on ecosystems and landscapes is not 
only vital for an appropriate interpretation and understanding of these systems today, but it also forms the baseline for more informed prediction about their potential future development (Christensen 1989; Boyden 1993; Pickett and McDonnell 1993; Bürgi and Russell 2001).

Consequently, it is important to link history and ecology, as stated in the subtitle of Emily (Russell) Southgate's book on "People and the land through time" (Russell 1997). Certainly, the claim is not new. Attempts to integrate humans in ecologically oriented research have long been made in several international long-term research programs, such as the MAB-Program (http://www.unesco.org/mab/), LTER (http://www.lternet.edu/), or PAGES (http:// www.pages.unibe.ch/), especially with its focus 5 "Past Ecosystems Processes and HumanEnvironment Interactions" and therein its activity HITE ("Human Impact on Terrestrial Ecosystems"). The HITE research plan begins with a clear statement for a historical-ecological approach: "Earth system science recognizes that knowledge of the history of environmental variability and human-environment interactions improves our understanding of the functioning of earth systems and their response to current and future impacts" (HITE 2006). These programs are implementing a historical approach at both the landscape as well as the ecosystem level.

In the study of human impacts on ecosystems and landscapes over time, three major objectives may be distinguished: (a) preserving cultural heritage in ecosystems and landscapes, (b) understanding historical trajectories of pattern and processes in ecosystems and landscapes, and (c) informing ecosystem and landscape management. In the following, we propose in a first section historical ecology as an approach that ideally combines these three objectives. The three objectives are then discussed in separate sections, each of which is illustrated with studies on a largely forgotten traditional forest use in Central Europe with a potentially high impact on forest ecosystems, i.e., litter collecting.

\section{Historical ecology}

Several disciplines have developed an interest in studying human-nature interaction over time. Among them are historical geography, environmental history, landscape ecology, anthropology, and archaeology. However, convincing concepts of how to integrate the human dimension, e.g., culture, into ecologically oriented studies of landscapes and ecosystems are still scarce (Nassauer 1995).

Although historical ecology is a comparatively new approach, various definitions and directions already exist. Three main branches can be distinguished. A first group of scientists locates historical ecology mainly in the context of anthropology and the social sciences (e.g., Crumley 1994; Balée 1998). They focus on basic research with the aim of an integrative understanding of human-nature interactions. A second group of scientists encompasses ecologists and landscape ecologists who integrate the human dimension in the analysis of pattern and processes in landscapes and ecosystems (e.g., Bürgi et al. 2000; Hellberg et al. 2003; Foster and Motzkin 2003). Finally, a third group is foremost located in the field of restoration ecology and ecological planning (e.g., Marcucci 2000; Egan and Howell 2001; Hessl 2002; Dirkx 2004). In this paper we follow a broad understanding of historical ecology as the study of human impacts on ecosystems and landscapes over time, embracing the three major objectives mentioned in the introduction and integrating approaches and objectives of all three main branches of historical ecology.

It is characteristic of historical ecology that a multitude of methods and data are used (Sheail 1980; Rackham 1980; Russell 1997; Egan and Howell 2001; Bürgi et al. 2007). Sources used include historical documents, such as maps (e.g., Ewald 1978; Kienast 1993; Petit and Lambin 2002), management plans (e.g., Östlund et al. 1997; Bürgi 1999; Axelsson et al. 2002), land survey records (e.g., Batek et al. 1999; Bürgi et al. 2000; Schulte et al. 2002), repeat photography, be it aerial (e.g., Miller 1999) or terrestrial (e.g., Tanner 1999; Skovlin et al. 2001; Nüsser 2001), and oral history interviews (e.g., Fogerty 2001, Gimmi and Bürgi 2007). Yet historical ecology also taps into various biological archives, such as tree rings (e.g., Veblen and Lorenz 1986; McLachlan et al. 2000), pollen, diatoms and charcoal sediments (e.g., Davis 1973; Foster 1992; Lotter 1998), fire scars and bark peelings (e.g., Larsen 1996; Östlund et al. 2003), archaeological evidence (e.g., Cousins et al. 2002), and last but not least ecosystems and landscapes themselves (Russell 1997). Of course, 
such data sources are also used in studies which do not explicitly claim to be part of historical ecology.

By combining these various approaches, methods and sources in the same project, historical ecologists inevitably venture onto the unsafe grounds of interdisciplinarity with its specific potential and obstacles (Naiman 1999; Pickett et al. 1999). Doing so properly demands that historical ecologists abstain from over-interpreting the historical sources they work with. In other words: historical ecology has to follow the requirements of a source critical approach as commonly used in historical sciences (Forman and Russell 1983; Edmonds 2001). Careful testing and evaluation, if possible by comparison of different source types or statistical methods, is crucial (e.g., Tinner et al. 1998; Manies and Mladenoff 2000; Mladenoff et al. 2002; Bolliger et al. 2004). Following the scientific standards of historical sciences goes parallel to considering approaches not commonly used in ecology, such as descriptive approaches, inferential reasoning, incorporating circumstantial evidence, and narratives (e.g., Allen et al. 2001; Hessburg and Agee 2003).

\section{Preserving cultural heritage in ecosystems and landscapes}

Global change has far-reaching cultural consequences (Arizpe 1996), including the steady loss of traditional land use systems worldwide (Plieninger et al. 2006) - a process which is both a consequence, and a core feature of global change. Only a few decades after a specific land use has been given up, i.e., when the people who actively performed the use have died, the traditional knowledge that went with it will also be gone forever, unless it has been collected and preserved.

This loss of traditional knowledge is a deterioration of global cultural heritage-and it is highly relevant for historical ecology, as historical ecology requires information on ecosystem and landscape history as well as on traditional land use and management. Understanding anthropogenic impacts on landscapes and ecosystems requires detailed information of the relevant human activities. Therefore, historical ecology has a deep interest in preserving knowledge on the cultural heritage related to land use and to collect traditional knowledge especially on land use systems which are not well documented and/or do not leave obvious traces on the land.

Case study on litter collecting: traditional knowledge at threat

In order to interpret changes in forest composition, we need to know what natural and anthropogenic disturbances have shaped a given stand. Unfortunately, we cannot take for granted that the ecologically most relevant human activities are necessarily recorded and documented in written historical records. One such poorly documented activity with potentially high impacts on forest ecosystems is litter collecting, a traditional forest use in Central Europe which was mostly performed by children and women (Fig. 1). Leaves and needles were collected to be used in stables especially after indoor feeding of cattle became more popular during the "agricultural revolution" towards the end of the 18th and the beginning of the 19th centuries (Bürgi 1999; Stuber and Bürgi 2002). In some areas, mattresses and beddings were also filled with dry leaves from the forest (Roth and Bürgi 2006). From scattered sources we know that many forest stands in Central Europe were denuded yearly of their litter (Glatzel 1990; Gimmi and Bürgi 2007). Unlike logging and burning, this anthropogenic disturbance did not leave any easily visible traces in

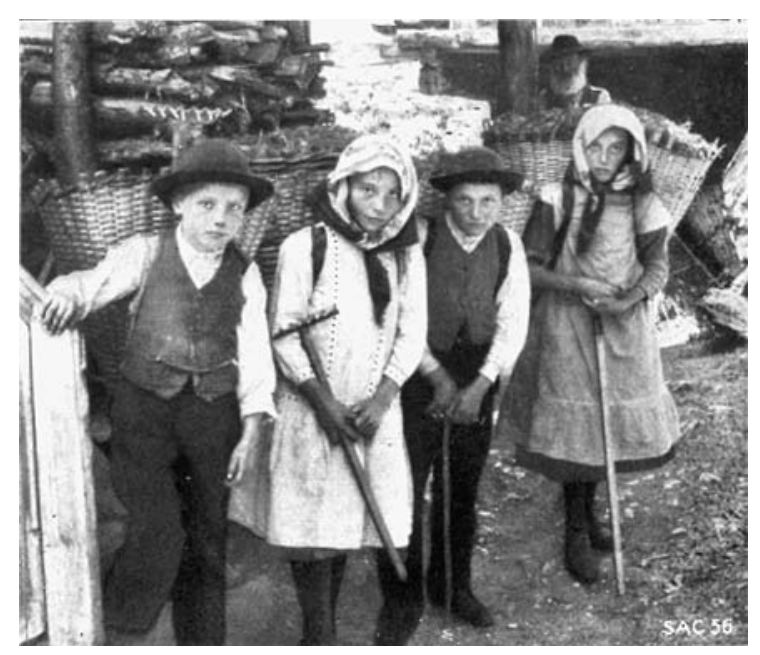

Fig. 1 "Return from forest litter collecting", picture taken in the 1920s in Eggwald, Zeneggen, canton of Valais, Switzerland (reproduced in Stebler 1922) 
the stands. The lack of unambiguous traces and the scarcity of historical documents make it nearly impossible to reconstruct the specific regime of this former use-unless firsthand information from the people who performed it can be collected with oral history interviews.

Conducting oral history interviews has proved in several studies to be a valuable method of collecting and preserving the vanishing wealth of traditional knowledge on litter collecting. Following two regional case studies (Roth and Bürgi 2006; Gimmi and Bürgi 2007), a more encompassing oral history study on traditional forest uses in Switzerland has recently been started, from which additional information on the local and regional variability in uses such as litter collecting will be saved from disappearing from the collective memory.

\section{Understanding historical trajectories}

In 1979, John Sheail wrote: "If the ecologist is to understand the processes taking place in the environment, close reference must be made to the effects of past land use and management" (Sheail 1979). In recent years, ecologists have increasingly recognized that human and natural disturbances have interacted in the shaping of ecosystems and biodiversity in many regions of the world (Veblen and Lorenz 1986; Foster 1992; McDonnel and Pickett 1993; Larsen 1996; Foster et al. 1999; Motzkin et al. 1999; Pykälä 2000; Hessl and Graumlich 2002; Thornton et al. 2002; Foster et al. 2003; Lefort et al. 2003). Especially in densely populated regions, understanding ecosystem and landscape trajectories requires information on changing human impacts (e.g., Salbitano 1988; Schenk 1996; Kirby and Watkins 1998; Bürgi 1999; Pykälä 2000). Assessing the range, extent, and intensity of the human impact on ecosystems is also highly relevant for long-term ecological research (Whitney and Somerlot 1985; Magnuson 1990; Swanson and Sparks 1990) and for the development of sustainable ecosystem management strategies (Wohlgemuth et al. 2002).

The ways human activities influence present pattern and processes in ecosystems and landscapes are manifold (Fig. 2) and a gradient exists from (near-)natural ecosystems, to anthropogenically altered ecosystems, to ecosystems which are completely anthropogenic. Whereas natural ecosystems are shaped by stand factors and natural disturbances, anthropogenically altered ecosystems additionally experience the direct impact of anthropogenic disturbances. Human activities also modify the disturbance natural disturbance regimes and influence stand factors, such as climate and soils. Soils are often the ecosystem component with the longest memory (Koerner et al. 1997, 1999; Dzwonko and Gawronski 2002; Dupouey et al. 2002; Falkengren-Grerup et al. 2006), but flora (Donohue et al. 2000; Rees et al. 2001; Poschlod and WallisDeVries 2002; Pardo and Gil 2005) and fauna (Knick and Rotenberry 2000; Jackson et al. 2001; Litvaitis et al. 2006) also reflect past human impacts.

If the relevant sources are available, historical analyses may provide vital information on human activities as well as on historical pattern and processes in ecosystems and landscapes. However, it is no simple task to assess causalities rather than correlations between the two. Comparative analyses, experiments, and modelling provide valuable additional insight into the dynamics and mechanisms of the system under study. Comparative analyses are especially suited to disentangling the human imprint on the land between regions which differ in land use histories but are similar in their environmental conditions (e.g., Bürgi et al. 2000). Experiments further help to assess the specific effects of land use systems, e.g., by monitoring vegetation change

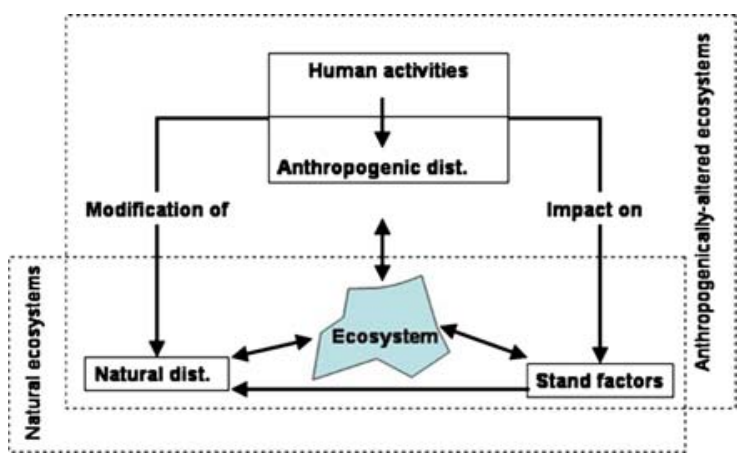

Fig. 2 Human activities influence present pattern and processes in ecosystems and landscapes in various ways. Whereas natural ecosystems are shaped by stand factors and natural disturbances, anthropogenically altered ecosystems additionally experience the direct impact of anthropogenic disturbances. Additionally, human activities modify the disturbance regime of the natural disturbances and they influence the stand factors, such as climate and soils 
resulting from reintroduced pasture (Bakker 1989) or litter collecting (Sayer 2006). The results of such experiments not only supplement ecologists' understanding of dynamics in ecosystems under human influence, but also provide valuable information for conservation and restoration. The main contribution of modelling to historical ecology lays in its ability to assess long-term consequences of human impacts on ecosystems, such as the long-term changes in carbon and/or nitrogen pools and fluxes (Perruchoud et al. 1999; Caspersen et al. 2000; Parton et al. 2005) or in energy balance (Cusso et al. 2006).

Understanding historical trajectories of pattern and processes in ecosystems and landscapes stands at the core of many ecological projects. The stronger the human imprint on an ecosystem or landscape is, the more vital is the integration of historical information in the ecological analysis.

Case study on litter collecting: the ecological imprint

In a study on the 20th century carbon budget of forest soils in the Swiss Alps, Perruchoud et al. (1999) deplore the lack of reliable data on litter collecting. Such data would not only be relevant for assessing changes in carbon stocks and fluxes, but also for forest ecosystem development in general. Several recent studies shed more light on the relevance of litter collecting, but the intensity of litter collecting and its spatial and temporal variability remains largely unknown.

Dzwonko and Gawronski (2002) showed that current vegetation composition in mixed oak-pine woodland in Poland is associated with past biomass removal by people. In a 16-year litter removal experiment, they found that continuous litter removal resulted in substantial soil impoverishment. Glatzel (1990) mentions nutrient depletion and reduced acid neutralizing capacity as the most severe effects of biomass removal.

The literature contains ample data on litter productivity and its nutrient content. However, is difficult to assess how much of this litter was actually removed annually. Old photographs imply that the quantities of litter removed from the forest were quite significant (Figs. 3 and 4) - but as sources of scientific data they have merely anecdotal value.
There are a few contemporary estimates on forest litter collection, such as a study on the Swiss canton of Uri by Müller (1892, in Stuber and Bürgi 2002) who estimated, based on cattle statistics, an annual demand of 5, 500 metric tons of forest litter for the whole canton. As the available forest area was 11,000 ha, an average of 0.5 tons of litter may have been removed annually from every hectare. Studying the history of litter collecting in a few communities in the Swiss canton of Valais, Gimmi et al. (submitted) determined that annual litter removal amounted to about 2-3 tons per hectare for selected forest stands. In a regional case study focussing on litter collecting for mattresses and bedding, Roth and Bürgi (2006) report an average demand of $1.3 \mathrm{~m}^{3}$ of dry beech leaves per person. How intensively this demand affected forest ecosystems, depended consequently of the per capita availability of accessible beech stands. In all cases, these numbers refer to average values, i.e., we have to expect a high spatial variability in how intensively this anthropogenic disturbance affected forest ecosystems.

The historical photographs of litter collecting (Fig. 3 and 4) suggest how relevant it is to consider the ecological consequences of this traditional forest use. Therefore, reconstructing the historical trajectories of e.g., carbon and nutrient fluxes in forest stands affected by litter collecting, requires detailed spatiotemporal information of this anthropogenic disturbance. This task has to be taken on by ecologists and historians together.

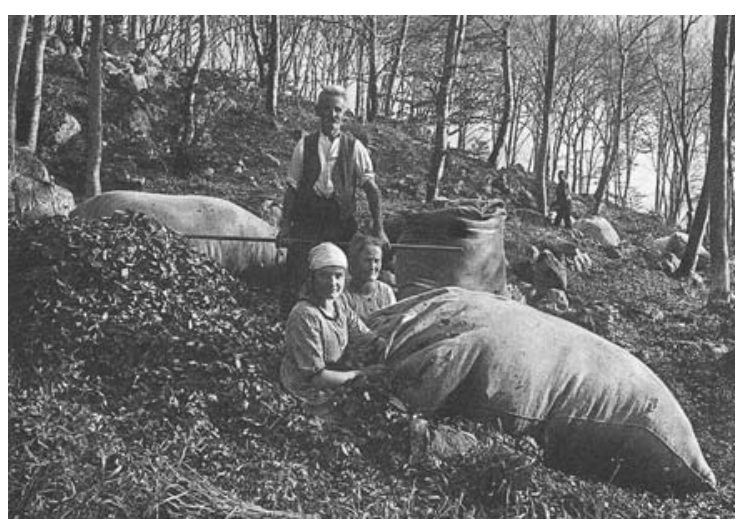

Fig. 3 Litter collecting day in Betlis (canton St. Gallen, Switzerland): The whole community is out in the beech stands to collect dry leaves to fill their mattresses and beddings (reproduced in Brockmann-Jerosch 1928/30) 


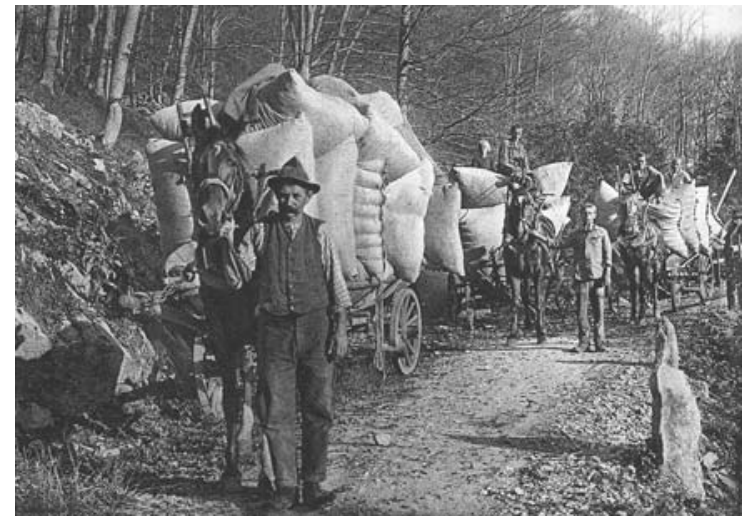

Fig. 4 Litter collecting day in Betlis (canton St. Gallen, Switzerland): In the evening, the beech leaves harvested are carried back home by horse and wagon (reproduced in Brockmann-Jerosch 1928/30)

\section{Informing ecosystem and landscape management}

Among the first classics on linking history and ecology for nature conservation and management are Oliver Rackham's “Ancient woodlands” (Rackham 1980) and George Peterken's “Woodland conservation and management" (Peterken 1981). Both authors focus on forest ecosystems, which are characterized by slow changes and long time lags between impacts and effects (e.g., Magnuson 1990). These characteristics of forest ecosystems clearly show the need for integrating history into ecologically oriented studies.

Several aspects where historical ecology becomes relevant for landscape management can be distinguished. If preservation is the aim, i.e., the protection of the remaining comparatively natural ecosystems such as ancient or old-growth forests (Rackham 1980; Wulf 1997; Graae et al. 2003), information on the regional history of human impacts is needed to know where this impact has been minimal and where consequently the areas to preserve are located (e.g., Rolstad et al. 2002). Restoration, on the other hand, is not limited to efforts of restoring systems to a "pristine" or "untouched" state, but is also concerned with restoring ecologically or also aesthetically desired cultural landscapes or anthropogenic ecosystems (e.g., Foster and Motzkin 2003). Examples of the latter are coppice forests, ecologically valuable pastureland or parks and gardens. Restoration projects require knowledge of former processes in ecosystems and landscapes and not only on their pattern and appearance. Consequently, information about past disturbance regimes, whether these were natural (e.g., fire frequency, flooding events, predator-prey interaction) or anthropogenic (grazing pressure, forestry practices, wildlife harvest) may be more useful to restoration practitioners than static descriptions of past ecosystem states. Detailed information about the history of land use practices is thus needed to assess potential impacts and evaluate consequences for future management (Eberhardt et al. 2003). In the field of restoration ecology, i.e., the science of how to bring back former ecosystem pattern and processes (Radeloff et al. 2000; Egan and Howell 2001; Foster and Motzkin 2003; Robertson and McGee 2003), historical ecology consequently finds various applications (i.e., applied historical ecology: Swetnam et al. 1999).

The comparatively new concept of historical variability (Landres et al. 1999), also called historical range of variability (Hessburg et al. 1999), provides a valuable framework for organizing information about historical changes in disturbance regimes (e.g., Hellberg 2004). Historical variability concepts are based on the insight that knowledge of historical pattern and processes as reference conditions is a prerequisite to informed land management (Parsons et al. 1999). However, it is often difficult if not impossible to identify and obtain appropriate data about reference conditions. Additionally, ongoing global (climate) change might alter the general conditions to a degree that severely limits the significance of information on the historical variability of ecosystem states and its related disturbance regime for restoration projects.

On a more general level, ecologists and managers may want to keep in mind the words of the environmental historian William Cronon (2000): "Effective land management must be responsible not just to ecology, but to history as well". How such a responsibility is taken on exactly, depends foremost on the cultural context. Artefacts from specific past land uses might well be looked upon in one region as something valuable which has to be protected and maybe even restored. In another part of the world they may be regarded as something which has to be removed to restore a more "natural" state of the ecosystem. In any case, for informed decisions on restoring or removing anthropogenic elements and impacts, detailed information on the relevant land use system and its consequences is needed. 
Case study on litter collecting: a new tool for nature conservation?

For centuries, central European forests have been intensively used. Apart from logging, anthropogenic disturbances included many traditional uses, such as wood pasture and litter collecting (Bürgi 1999). Following the reduction of these anthropogenic disturbances in the 19th and 20th centuries, a change in species composition was recorded (Wohlgemuth et al. 2002). Decreasing average light-indicator values and increasing nutrient-indicator values suggest that the forests became darker and richer in nutrients-which would correspond well with the likely effects of reduced anthropogenic disturbances, such as litter collecting. Today's central European forests might be more natural in some aspects compared to the situation in the 18th and 19th century, but species dwelling on soils with low levels of nutrients and high levels of light availability have become extinct in many forest stands (literature in Wohlgemuth et al. 2002). Consequently, nature conservation measures have been developed to alter the light regime on forest floors. But what about the nutrient conditions? Evaluating the disturbance history suggests that traditional forest uses primarily resulted in biomass removal and lowered the nutrients availability. Consequently, in 2003, we started an experiment in 16 beech stands in the Swiss lowlands, to study the effects of litter removal on flora and soil chemistry (Bürgi et al. 2006). No quick results can be expected: A similar experiment in Poland (Dzwonko and Gawronski 2002) showed significant effects of litter removal after 16 years in mixed oak-pine stands. However, financial support by state agencies underlines the interest of practitioners in evaluating whether litter collecting might be an additional tool for nature conservation to locally foster species which suffer from the abandonment of traditional forest uses.

\section{Conclusions}

Both ecological research and land management take place in a specific cultural setting. This setting leaves its imprint on the scientific questions asked as well as on the management goals pursued. History is part of this cultural setting - by shaping the value systems of scientists and land mangers alike, and by forming the ecosystems and landscapes under study and management. Based on the considerations outlined above, it seems likely that ecology and management, scientists and land mangers will profit greatly from integrating historical information into their analyses and management schemes. On first sight, historical information might simply complicate studies on pattern and processes in ecosystems and landscapes-especially if the data taken from historical sources do not fully correspond with the rigid requirements of traditional scientific analyses. However, the alternative to dealing with incomplete and qualitative information is to ignore the historical dimension-and consequently to run the risk of greatly misinterpreting the ecological data recorded today.

Similarly, information on the history of landscapes and ecosystems does not provide answers on how to manage the land in a straightforward manner: How it was in the past, might not be how we want it to be in the future. The discussion of how to manage, and in which direction to develop a landscape or an ecosystem has to be based on present values and should consider the various needs and demands of modern societies. But it is crucial to be aware that this discussion is on safer grounds, if historical information is considered. And if a decision on the direction and goals has been taken, historical ecology provides valuable information on how this direction might best be followed and how the goals might be achieved.

In this paper, three objectives of historical ecology are distinguished, i.e., (a) preserving cultural heritage in ecosystems and landscapes, (b) understanding historical trajectories of pattern and processes in ecosystems and landscapes, and (c) informing ecosystem and landscape management. Together, these three objectives ensure that valuable historical information is preserved and can help the scientific community to better understand the trajectories of change as well as support land managers in their task to manage ecosystems and landscapes sustainably.

Acknowledgements The ideas and concepts presented in this paper are based on discussions with many scholars, from whom we would like to especially mention Anton Schuler, Glenn Motzkin, Lars Östlund, Emily W.B. Southgate (Russell) and Niklaus E. Zimmermann. 


\section{References}

Allen TFH, Tainter JA, Pires JC, Hoekstra TW (2001) Dragnet ecology - "just the facts, ma'am": the privilege of science in a postmodern world. BioScience 51:475-485

Arizpe L (ed) (1996) The cultural dimensions of global change. UNESCO Publishing, Paris

Axelsson AL, Östlund L, Hellberg E (2002) Changes in mixed deciduous forests of boreal Sweden 1866-1999 based on interpretation of historical records. Landsc Ecology 17:403-418

Bakker JP (1989) Nature management by grazing and cutting. Kluwer Academic Publishers, Dordrecht

Balée W (ed) (1998) Advances in historical ecology. Columbia University Press, New York

Batek MJ, Rebertus AJ, Schroeder WA, Haithcoat TL (1999) Reconstruction of early nineteenth-century vegetation and fire regimes in the Missouri Ozarks. J Biogeogr 26:397412

Berger J (1987) Guidelines for landscape synthesis: some directions-old and new. Landsc Urban Plan 14:295-311

Birks HH, Birks HJB, Kaland PE, Moe D (1988) The cultural landscape - past, present and future. Cambridge University Press, Cambridge

Bolliger J, Schulte LA, Burrows SN, Sickley TA, Mladenoff DJ (2004) Assessing ecological restoration potentials of Wisconsin (USA) using historical landscape reconstructions. Restor Ecol 12:124-142

Boyden S (1993) The human component of ecosystems. In: McDonnell MJ, Pickett STA (eds) Humans as components of ecosystems. Springer, Berlin Heidelberg New York, pp 72-77

Brockmann-Jerosch H (ed) (1928/30) Schweizer Volksleben. 2 Vol. Erlenbach, Zurich

Bürgi M (1999) A case study of forest change in the Swiss lowlands. Landsc Ecol 14:567-575

Bürgi M, Russel EWB (2001) Integrative methods to study landscape changes. Land Use Policy 18:9-16

Bürgi M, Russell EWB, Motzkin G (2000) Effects of postsettlement land-use history on forest composition in the north-eastern United States - a comparative approach. J Biogeogr 27:1123-1138

Bürgi M, Wohlgemuth T, Zimmermann S (2006) Austragsnutzungen im Wald. Zürcher Wald 5:28f

Bürgi M, Hersperger AM, Hall M, Southgate (Russell) EWB, Schneeberger N (2007) Using the past to understand the present land use and land cover. In: Kienast F, Wildi O, Gosh S (eds) A changing world. Challenges for landscape research. Springer Landscape Series 8, pp 133-144

Caspersen JP, Pacala SW, Jenkins JC, Hurtt GC, Moorcroft PR, Birdsey RA (2000) Contributions of land-use history to carbon accumulation in US forests. Science 290:11481151

Christensen NL (1989) Landscape history and ecological change. J Forest Hist 33:116-125

Cousins SAO, Eriksson A, Franzen D (2002) Reconstructing past land use and vegetation patterns using palaeogeographical and archaeological data - a focus on grasslands in Nynas by the Baltic Sea in south-eastern Sweden. Landsc Urban Plan 61:1-18
Cronon W (2000) Resisting monoliths and tabluae rasae. Ecol Appl 10:673-675

Crumley CL (1994) Historical ecology cultural knowledge and changing landscapes. School of American Research Press, Santa Fe

Crumley CL (1998) Foreword. In: Balée W (ed) Advances in historical ecology. Columbia University Press, New York, pp ix-xiv

Cusso X, Garrabou R, Tello E (2006) Social metabolism in an agrarian region of Catatonia (Spain) in 1860-1870: flows, energy balance and land use. Ecol Econ 58:49-65

Davis MB (1973) Pollen evidence of changing land use around the shores of Lake Washington. Northwest Sci 47:133148

Dirkx J (2004) Historical ecology of Dutch cultural landscapes: references for the integration of landscape planning and nature restoration in the Netherlands. In: Brandt J, Vejre H (eds) Multifunctional landscapes. I: theory, values and history. WIT Press, Southampton Boston, pp 137-149

Donohue K, Foster DR, Motzkin G (2000) Effects of the past and the present on species distribution: land-use history and demography of wintergreen. J Ecol 88:303-316

Dupouey JJ, Dambrine E, Laffite JD, Moares C (2002) Irreversible impact of past land use on forest soils and biodiversity. Ecology 83:2978-2984

Dzwonko Z, Gawronski S (2002) Effect of litter removal on species richness and acidification of a mixed oak-pine woodland. Biol Conserv 106:389-398

Eberhardt RW, Foster DR, Motzkin G, Hall B (2003) Conservation of changing landscapes: vegetation and land-use history of Cape Cod National Seashore. Ecol Appl 13:68-84

Edmonds M (2001) The pleasures and pitfalls of written records. In: Egan D, Howell EA (eds) The historical ecology handbook. Island Press, Washington, pp 73-99

Egan D, Howell EA (2001) The historical ecology handbook. Island Press, Washington, DC

Ewald KC (1978) Der Landschaftswandel. Zur Veränderung schweizerischer Kulturlandschaften im 20. Jahrhundert. Berichte Eidgenössische Anstalt für das forstliche Versuchswesen, 191

Falkengren-Grerup U, ten Brink DJ, Brunet J (2006) Land use effects on soil N, P, C and pH persist over 40-80 years of forest growth on agricultural soils. Forest Ecol Manage 225:74-81

Fogerty JE (2001) Oral history: a guide to its creation and use. In: Egan D, Howell EA (eds) The historical ecology handbook. Island Press, Washington, pp 101-120

Forman RTT, Russell EWB (1983) Evaluation of historical data in ecology. Bull Ecol Soc Am 64:5-7

Foster DR (1992) Land-use history (1730-1990) and vegetation dynamics in central New England, USA. J Ecol 80:753-772

Foster DR, Motzkin G (2003) Interpreting and conserving the openland habitats of coastal New England: insights from landscape history. Forest Ecol Manag 185:127-150

Foster DR, Fluet M, Bose ER (1999) Human or natural disturbance: landscape-scale dynamics of the tropical forests of Puerto Rico. Ecol Appl 9:555-572 
Foster D, Swanson F, Aber J, Burke I, Brokaw N, Tilman D, Knapp A (2003) The importance of land-use legacies to ecology and conservation. BioScience 53:77-88

Gimmi U, Bürgi M (2007) Using oral history and forest management plans to reconstruct traditional non-timber forest uses in the Swiss Rhone valley (Valais) since the late 19th century. Environ Hist 13:211-246

Gimmi U, Bürgi M, Stuber M (submitted) Reconstructing anthropogenic disturbance regimes in forest ecosystems a case study from the Swiss Rhone valley. Ecosystems

Glatzel G (1990) The nitrogen status of Austrian forest ecosystems as influenced by atmospheric deposition, biomass harvesting and lateral organomass exchange. Plant Soil 128:67-74

Goudie A (1981) The human impact on the natural environment. Blackwell, Malden

Graae BJ, Sunde PB, Fritzboger B (2003) Vegetation and soil differences in ancient opposed to new forests. Forest Ecol Manag 177:179-190

Hammett JE (1992) The shapes of adaptation: historical ecology of anthropogenic landscapes in the Southeastern United States. Landsc Ecol 7:121-135

Hellberg E (2004) Historical variability of deciduous trees and deciduous forests in Northern Sweden Effects of forest fires, land-use and climate. Acta Universitatis Agriculturae Sueciae Silvestria 308

Hellberg E, Hörnberg G, Östlund L, Zackrisson O (2003) Vegetation dynamics and disturbance history in three deciduous forests in boreal Sweden. J Vege Sci 14:267276

Hessburg PE, Agee JK (2003) An environment narrative of Inland Northwest United States forests, 1800-2000. Forest Ecol Manag 178:23-59

Hessburg PE, Smith BG, Salter RB (1999) Detecting change in forest spatial patterns from reference conditions. Ecol Appl 9:1232-1252

Hessl A (2002) Aspen, elk and fire: the effects of human institutions on ecosystem processes. BioScience 52:10111022

Hessl AE, Graumlich LJ (2002) Interactive effects of human activities, herbivory and fire on quaking aspen (Populus tremulus) age structure in western Wyoming. J Biogeogr 29:889-902

HITE (2006) HITE research plan. http://www.liv.ac.uk/ geography/research_projects/Hite/Scipaln.htm (cited $23 \mathrm{Jul}$ 2007). Organization site

Jackson JBC, Kirby MX, Berger WH, Bjorndal KA, Botsford LW, Bourque BJ, Bradbury RH, Cooke R, Erlandson J, Estes JA, Hughes TP, Kidwell S, Lange CB, Lenihan HS, Pandolfi JM, Peterson CH, Steneck RS, Tegner MJ, Warner RR (2001) Historical overfishing and the recent collapse of coastal ecosystems. Science 293:629-638

Kienast F (1993) Analysis of historic landscape patterns with a Geographical Information System - a methodological outline. Landsc Ecol 8:103-118

Kirby KJ, Watkins C (1998) The ecological history of European forests. CAB International, Cambridge

Knick ST, Rotenberry JT (2000) Ghosts of habitats past: contribution of landscape change to current habitats used by shrubland birds. Ecology 81:220-227
Koerner W, Dupouey JL, Dambrine E, Benoit M (1997) Influence of past land use on the vegetation and soils of present day forest in the Vosges mountains, France. J Ecol 85:351-358

Koerner W, Dambrine E, Dupouey JL, Benoit M (1999) $15 \mathrm{~N}$ of forest soil and understorey vegetation reflect the former agricultural land use. Oecologia 121:421-425

Landres PB, Morgan P, Swanson FJ (1999) Overwiew of the use of natural variability concepts in managing ecological systems. Ecol Appl 9:1179-1188

Larsen CPS (1996) Fire and climate dynamics in the boreal forest of northern Alberta, Canada, from AD 1850 to 1989. Holocene 6:449-456

Lefort P, Gauthier S, Bergeron Y (2003) The influence of fire weather and land use on the fire activity of the Lake Abitibi area, eastern Canada. Forest Sci 49:509-521

Litvaitis JA, Tash JP, Stevens CL (2006) The rise and fall of bobcat populations in New Hampshire: relevance of historical harvests to understanding current patterns of abundance and distribution. Biol Conserv 128:517-528

Lotter AF (1998) The recent eutrophication of Baldeggersee (Switzerland) as assessed by fossil diatom assemblages. Holocene 8:395-405

Magnuson JJ (1990) Long-term ecological research and the invisible present. BioScience 40:495-501

Manies KL, Mladenoff DJ (2000) Testing methods to produce landscape-scale presettlement vegetation maps from the US public land survey records. Landsc Ecol 15:741-754

Marcucci DJ (2000) Landscape history as a planning tool. Landsc Urban Plan 49:67-81

Marsh GP (2003) Men and nature (reprint edited by Lowenthal D). University of Washington Press, Seattle London

McDonnell MJ, Pickett STA (1993) Humans as components of ecosystems - the ecology of subtle human effects and populated areas. Springer, New York

McLachlan JS, Foster DR, Menalled F (2000) Anthropogenic ties to late-successional structure and composition in four New England hemlock stands. Ecology 81:717-733

Miller ME (1999) Use of historic areal photography to study vegetation change in the Negrito Creek watershed, southwestern New Mexico. Southwest Nat 44:121-137

Mladenoff DJ, Dahir SE, Nordheim EV, Schulte LA, Guntenspergen GG (2002) Narrowing historical uncertainty: probabilistic classification of ambiguously identified tree species in historical forest survey data. Ecosystems 5:539-553

Motzkin G, Wilson P, Foster DR, Allen A (1999) Vegetation patterns in heterogeneous landscapes: the importance of history and environment. J Vege Sci 10:903-920

Müller A (1892) Die Streunutzung in den Hochgebirgswaldungen. Schweizerische Zeitschrift für Forstwesen 43:100106

Naiman RJ (1999) A perspective on interdisciplinarity science. Ecosystems 2:292-295

Nassauer JI (1995) Culture and changing landscape structure. Landsc Ecol 10:229-237

Nassauer JI (ed) (1997) Placing nature culture and landscape ecology. Island Press, Washington

Nüsser M (2001) Understanding cultural landscape transformation: a re-photographic survey in Chitral, eastern Hindukush, Pakistan. Landsc Urban Plan 57:241-255 
Östlund L, Zackrisson O, Axelsson AL (1997) The history and transformation of a Scandinavian boreal forest landscape since the 19th century. Can J Forest Res 27:1198-1206

Östlund L, Ericsson TS, Zackrisson O, Andersson R (2003) Traces of past Sami forest use: an ecological study of culturally modified trees and earlier land use within a boreal forest reserve Scandinavian. J Forest Res 18:78-89

Pardo F, Gil L (2005) The impact of traditional land use on woodlands: a case study in the Spanish Central System. J Hist Geogr 31:390-408

Parsons DJ, Swetnam TW, Christensen NL (1999) Uses and limitations of historical variability concepts in managing ecosystems. Ecol Appl 9:1177f

Parton WJ, Gutmann MP, Williams SA, Easter M, Ojima D (2005) Ecological impact of historical land-use patterns in the Great Plains: a methodological assessment. Ecol Appl 15:1915-1928

Perruchoud D, Kienast F, Kaufmann E, Braeker OU (1999) 20th century carbon budget of forest soils in the alps. Ecosystems 2:320-337

Peterken GF (1981) Woodland conservation and management. Chapman and Hall, London

Petit CC, Lambin EF (2002) Long-term land-cover changes in the Belgian Ardennes (1775-1929): model-based reconstruction vs historical maps. Global Change Biol 8:616630

Pickett STA, McDonnell MJ (1993) Humans as components of ecosystems: a synthesis. In: McDonnell MJ, Pickett STA (eds) Humans as components of ecosystems. Springer, New York, pp 310-316

Pickett STA, Burch WR, Grove JM (1999) Interdisciplinary research: maintaining the constructive impulse in a culture of criticism. Ecosystems 2:302-307

Plieninger T, Höchtl F, Spek T (2006) Traditional land-use and nature conservation in European rural landscapes. Environ Sci Policy 9:317-312

Poschlod P, WallisDeVries MF (2002) The historical and socioeconomic perspective of calcareous grasslands lessons from the distant and recent past. Biol Conserv 104:361-376

Pykälä J (2000) Mitigating human effects on European biodiversity through traditional animal husbandry. Conserv Biol 14:705-712

Rackham O (1980) Ancient woodland - its history, vegetation and uses in England. Edward Arnold, London

Radeloff VC, Mladenoff DJ, Boyce MS (2000) A historical perspective and future outlook on landscape scale restoration in the northwest Wisconsin pine barrens. Restor Ecol 8:119-126

Rees M, Condit R, Crawley M, Pacala S, Tilman D (2001) Long-term studies of vegetation dynamics. Science 293:650-655

Robertson HA, McGee TK (2003) Applying local knowledge: the contribution of oral history to wetland rehabilitation at Kanyapella Basin, Australia. J Environ Manag 69: 275-287

Rolstad J, Gjerde I, Gundersen VS, Saetersdal M (2002) Use of indicator species to assess forest continuity: a critique. Conserv Biol 16:253-257

Roth L, Bürgi M (2006) Bettlaubsammeln als Streunutzung im St. Galler Rheintal [Collecting leaves for beddings - a traditional forest use in the St. Galler Rheintal]. Schweizerische Zeitschrift für Forstwesen 8:348-356

Russell EWB (1997) People and the land through time: linking ecology and history. Yale University Press, New Haven

Salbitano F (ed) (1988) Human influence on forest ecosystems development in Europe. Pitagora, Bologna

Sayer EJ (2006) Using experimental manipulation to assess the roles of leaf litter in the functioning of forest ecosystems. Biol Rev 81:1-31

Schenk W (1996) Waldnutzung, Waldzustand und regionale Entwicklung in vorindustrieller Zeit im mittleren Deutschland. Franz Steiner, Stuttgart, Erdkundliches Wissen 117

Schulte LA, Mladenoff DJ, Nordheim EV (2002) Quantitative classification of a historic northern Wisconsin (USA) landscape: mapping forests at regional scales. Can J Forest Res 32:1616-1638

Sheail J (1979) Documentary evidence of the changes in the use, management and appreciation of the grass-heaths of Breckland. J Biogeogr 6:277-292

Sheail J (1980) Historical ecology: the documentary evidence. Natural Environment Research Council, Institute of Terrestrial Ecology, Huntington

Simmons IG (1989) Changing the face of the earth. Culture, environment, history. Basil Blackwell, Oxford Cambridge

Skovlin JM, Strickler GS, Peterson JL, Sampson AW (2001) Interpreting landscape change in high mountains of northeastern Oregon from long-term repeat photography. USDA Forest Service, Pacific Northwest Research Station General Technical Report 505

Stebler FG (1922) Die Vispertaler Sonnenberge. In: Jahrbuch des Schweizerischen Alpen-Club 56, Berne

Stuber M, Bürgi M (2002) Agrarische Waldnutzungen in der Schweiz 1800-1950. Nadel- und Laubstreue [Agricultural use of forests in Switzerland 1800-1950. Needles and leaves for litter harvesting]. Schweizerische Zeitschrift für Forstwesen 153:397-410

Swanson FJ, Sparks RE (1990) Long-term ecological research and the invisible present. BioScience 40:502-508

Swetnam TW, Allen CD, Betancourt JL (1999) Applied historical ecology: using the past to manage for the future. Ecol Appl 9:1189-1206

Tanner KM (1999) Augen-Blicke: Bilder zum Landschaftswandel im Baselbiet. Verlag des Kantons BaselLandschaft, Liestal

Tinner W, Conedera M, Ammann B, Gäggeler HW, Gedye S, Jones R, Sägesser B (1998) Pollen and charcoal in lake sediments compared with historically documented forest fires in southern Switzerland since AD 1920. Holocene $8: 31-42$

Thornton PE, Law BE, Gholz HL, Clark KL, Falge E, Ellsworth DS, Golstein AH, Monson RK, Hollinger D, Falk M, Chen J, Sparks JP (2002) Modeling and measuring the effects of disturbance history and climate on carbon and water budgets in evergreen needleleaf forests. Agric Forest Meteorol 113:185-222

Turner BL (ed) (1990) The earth as transformed by human action. Global and regional changes in biosphere over the past 300 years. Cambridge University Press, Cambridge 
Veblen TT, Lorenz DC (1986) Antropogenic disturbance and recovery patterns in montane forests, Colorado Front Range. Phys Geogr 7:1-24

Vitousek PM, Mooney HA, Lubchenco J, Melillo JM (1997) Human domination of earth's ecosystems. Science 277:494-499

Whitney GG, Somerlot WJ (1985) A case study of woodland continuity and change in the American Midwest. Biol Conserv 31:265-287
Williams M (1993) An exceptionally powerful biotic factor. In: McDonnell MJ, Pickett STA (eds) Humans as components of ecosystems. Springer, pp 229-245

Wohlgemuth T, Bürgi M, Scheidegger C, Schütz M (2002) Dominance reduction of species through disturbance - a proposed management principle for central European forests. Forest Ecol Manag 166:1-15

Wulf M (1997) Plant species as indicators of ancient woodland in northwestern Germany. J Vege Sci 8:635-642 